\title{
APLIKASI CUSTOMER RELATIONSHIP MANAGEMENT (CRM) PADA BALAI KESEHATAN MASYARAKAT (BKM) MUSLIMAT KEPANJEN
}

\author{
Agustina Sulkanawatul $^{1}$, Hendra Pradibta ${ }^{2}$, Indra Dharma Wijaya ${ }^{3}$ \\ ${ }^{1,2,3}$ Teknik Informatika, Teknologi Informasi, Politeknik Negeri Malang \\ 1. sulkanawatulagustina@gmail.com, ${ }^{2}$ ndropradibta@yahoo.com, ${ }^{3}$ indra.dharma@gmail.com
}

\begin{abstract}
Abstrak
Penelitian ini betujuan untuk merancang aplikasi CRM yang berfungsi untuk menyediakan informasi kepada pelanggan atau pasien BKM Muslimat. Semakin bertambahnya pelanggan atau pasien, maka perlu untuk meningkatkan mutu pelayanan terhadap pelanggan demi keberlangsungan bisnis di BKM Muslimat Kepanjen. BKM Muslimat Kepanjen berusaha untuk memberikan pelayanan yang terbaik kepada pelanggan atau pasiennya dengan harapan untuk mendapatkan pelanggan atau pasien baru dan mempertahankan pelanggan atau pasien lama. Salah satu solusinya adalah aplikasi Customer Relationship Management (CRM) yang diterapkan dalam bentuk web. Aplikasi ini dibangun menggunakan bahasa pemrogaman PHP dan MySQL untuk perancangan database. Aplikasi ini dilengkapi dengan kuesioner online. Kuesioner ini berguna untuk mensurvey kepuasan pelanggan atau pasien BKM Muslimat Kepanjen. Dengan penerapan metode Algoritme K-means Clustering, penelitian ini menghasilkan tingkat kepuasan pelanggan terhadap kualitas pelayanan BKM Muslimat. Dengan penerapan metode Algoritme K-means Clustering dihasilkan 3 cluster akhir pada setiap kategori, dengan kategori empati yang memiliki prosentase kepuasan terendah, yaitu pada kategori empati dengan cluster tidak puas sebesar 63,64\%. Dengan tingkat kepuasan pelanggan yang telah diketahui maka pihak BKM Muslimat dapat mengambil suatu kebijakan evaluasi pada bidang-bidang pelayanan yang prosentase tingkat kepuasan pelayanannya kurang.
\end{abstract}

Kata kunci : Customer Relationship Management (CRM), e-CRM, web, k-means.

\section{Pendahuluan}

BKM Muslimat merupakan salah satu fasilitas kesehatan masyarakat di kepanjen tepatnya beralamat di Jl. Sultan Agung 12 Kepanjen. Awal mula berdiri BKM Muslimat bernama BKIA (Balai Kesehatan Ibu dan Anak) Muslimat. Pada waktu itu pelayanan yang diberikan hanya sebatas pelayanan persalinan. Seiring berjalan waktu BKIA Muslimat berubah menjadi BKM (Balai Kesehatan Masyarakat) Muslimat.

Sampai dengan saat ini, BKM Muslimat melakukan sistem pendataan pasien masih dilakukan secara manual (tercatat). Pendataan secara manual dianggap kurang efektif. Karena bertambahnya pelanggan atau pasien pada BKM Muslimat maka kualitas layanan tetap menjadi sesuatu yang sangat penting dalam menghadapi pelanggan. Pelayanan yang bermutu tinggi yang berarti mampu memberikan keselarasan terhadap kebutuhan pelanggan, Secara esensial, baik pelanggan kelas atas, menengah bahkan bawah sekalipun membutuhkan pelayanan yang baik dan bermutu, hanya saja tingkatannya yang berbedabeda. Keberadaan pelanggan bagi sebuah instansi saat ini bukan hanya sebagai sumber pendapatan perusahaan saja, melainkan juga sebuah aset jangka panjang yang perlu dikelola dan juga dipelihara melalui Customer Relationship Management (CRM) yang bertujuan untuk mampu menyediakan data dan informasi kepada pelanggan.

Customer relationship management (CRM) adalah strategi memperoleh, mengkonsolidasi dan menganalisis data pelanggan dan kemudian dipergunakan untuk berinteraksi dengan pelanggan (Kaswidjanti;2011:18). Aplikasi ini terdiri dari dua sistem, yaitu CRM Operasional dan CRM Analitik. Pengukuran pada CRM Analitik terhadap pasien BKM Muslimat menggunakan Algoritme K-means Clustering. Umpan balik dari CRM Operasional dengan menggunakan SMS Gateway. Dengan adanya aplikasi CRM pada BKM Muslimat ini dapat dijadikan solusi untuk menigkatkan mutu pelayanan pasien. 


\section{Studi Literatur}

Penelitian serupa pernah dilakukan oleh Adelia dan Jimmy Setiawan dari Universitas Kristen Maranatha Bandung tahun 2011, dengan judul Implementasi Customer Relationship Management (CRM) pada Sistem Reservasi Hotel berbasis Website dan Dekstop. Penelitian ini terdapat 2 aplikasi, yaitu Aplikasi Dekstop dan Website. Aplikasi Dekstop dibuat untuk mempermudah pihak hotel untuk mengelola data master sedangkan Aplikasi Website dibuat untuk memudahkan masyarakat untuk mendapatkan informasi mengenai hotel dan untuk melakukan pemesanan kamar secara online.

Aplikasi di dalam penelitian ini adalah aplikasi (CRM) BKM Muslimat dengan memanfaatkan teknologi internet yang berfungsi sebagai layanan bagi pelanggan atau pasien untuk menyediakan informasi yang dibutuhkan pelanggan atau pasien tanpa dibatasi jarak dan waktu. Aplikasi ini menyediakan informasi jadwal praktek dokter, layanan poli, rekam medis pasien, menyediakan fitur sms gateway untuk meningkatkan jadwal check-up pasiennya. Metode yang digunakan dalam penelitian ini yaitu metode waterfall dengan menggunakan bahasa pemrogaman PHP dan MySQL untuk perancangan database.

\section{Landasan Teori}

\subsection{Customer Relationship Management}

Customer Relationship Management adalah strategi memperoleh, mengkonsolidasi dan menganalisis data pelanggan dan kemudian diperguakan untuk berinteraksi dengan pelanggan.

\subsection{Klasifikasi Aplikasi CRM \\ - CRM Operasional}

CRM Operasional di kenal sebagai "front office" perusahaan. Aplikasi CRM ini berperan dalam interaksi dengan pelanggan. CRM Operasional mencakup proses otomatisasi yang terintegrasi dari keseluruhan proses bisnis, seperti otomatisasi pemasaran, penjualan, dan pelayanan.

Salah satu penerapan CRM yang temasuk dalarn kategori operasional CRM adalah dalam bentuk aplikasi web. Melalui web, suatu perusahaan dapat rnernberikan pelayanan kepada pelanggan.

- CRM Analisis

CRM Analitik dikenal sebagai "back office" perusahaan. Aplikasi CRM ini berperan dalarn memahami kebutuhan pelanggan. CRM Analitik berperan dalam melaksanakan analisis pelanggan dan pasar, seperti analisis trend pasar dan analisis perilaku pelanggan. Data yang digunakan pada CRM Analitik adalah data yang berasal dari CRM Operasional.

\subsection{Algoritme K-means}

K-means merupakan salah satu metode clustering non hirarki yang berusaha mempartisi data yang ada ke dalam bentuk satu atau lebih cluster. Metode ini mempartisi data ke dalam cluster sehingga data yang memiliki karakteristik yang sama dikelompokkan ke dalam satu cluster yang sama dan data yang mempunyai karateristik yang berbeda di kelompokan ke dalam cluster yang lain.

\section{Perancangan}

\subsection{Arsitektur Diagram}

Berdasarkan dari analisis kebutuhan perangkat lunak dalam pembuatan aplikasi, sistem dalam aplikasi ini memiliki proses atau alur kerja yang menggunakan proses terjadinya suatu transaksi dalam sistem tersebut. Proses atau alur kerja digambarkan pada arsitektur sistem pada gambar 1.

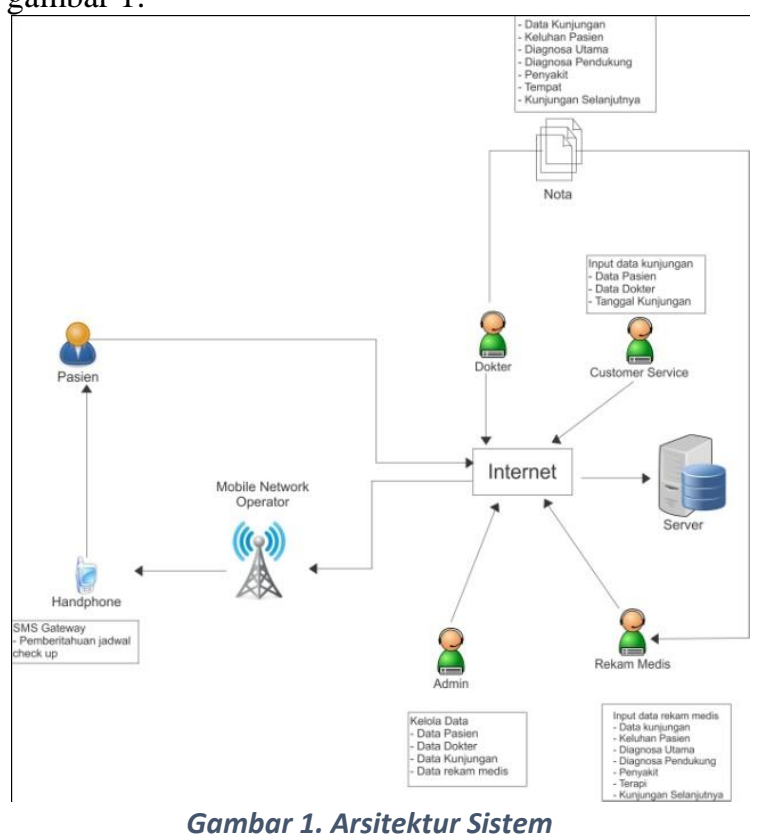

4.2 Diagram Konteks

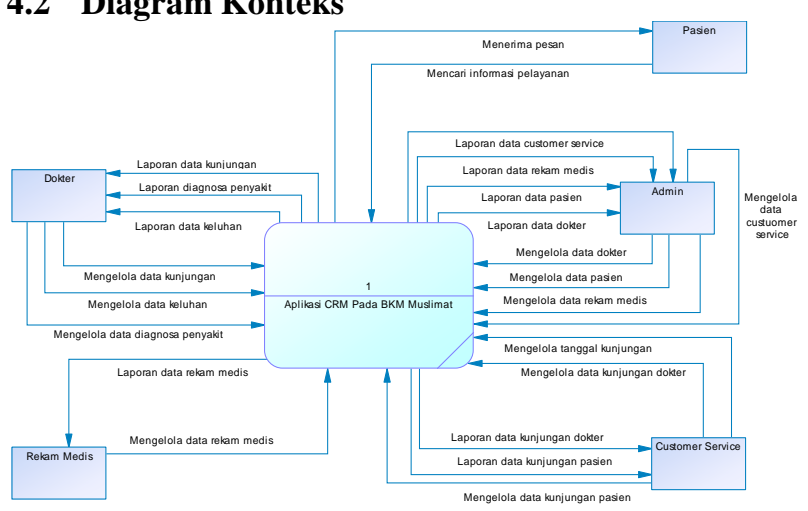

Gambar 2. Diagram Konteks 
Proses pada sistem diatas meliputi halaman admin, rekam medis, customer service, dokter, dan user biasa dalam hal ini adalah pasien. Seorang admin dalam sistem ini adalah user yang memiliki akses tertinggi. Sedangkan untuk user selain admin, hanya memiliki hak akses terbatas. Setiap user hanya dapat mengakses halam yang telah diatur oleh admin, dan tidak dapat interferensi terhadap fasilitas yang telah diberikan pada user lainnya.

\subsection{ER-Diagram}

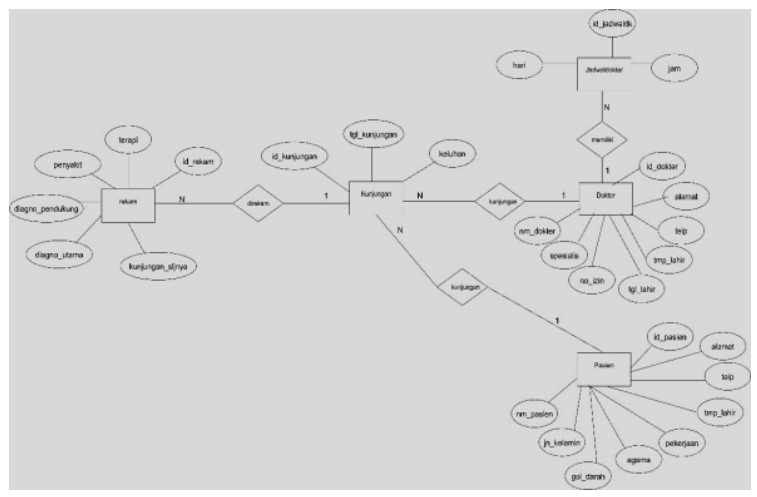

Gambar 3. ER-Diagram

Entity Relationship Diagram (ERD) merupakan suatu model untuk menjelaskan hubungan antar data dalam basis data berdasarkan objek-objek dasar data yang mempunyai hubungan antar relasi. ERD untuk memodelkan struktur data dan hubungan antar data, untuk menggambarkannya digunakan beberapa notasi dan simbol. Di dalam ERD aplikasi ini terdapat 5 Entity, yaitu: dokter, rekam, jadwal, kunjungan, dan pasien. Setiap entity memiliki atribut masingmasing.

\subsection{Work Breakdown Structure (WBS)}

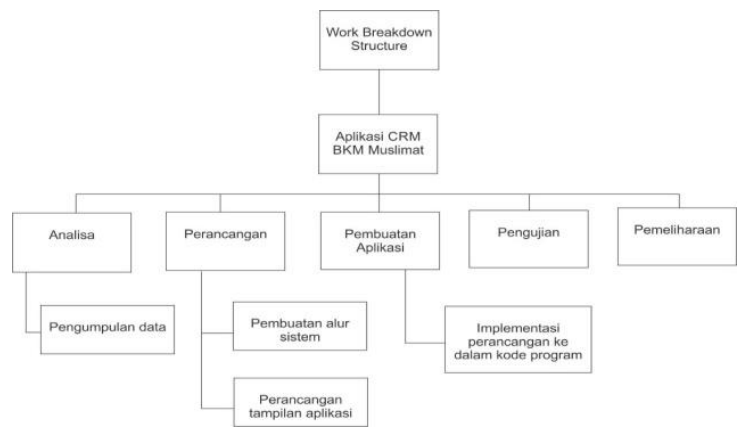

Gambar 4. Work Breakdown Structure

Dalam pembuatan dan pengembangan aplikasi diperlukan langkah-langkah seperti diatas, yaitu: analisa kebutuhan aplikasi, perancangan aplikasi, pembuatan aplikasi, pengujian pada aplikasi, dan selanjutanya pemeliharaan aplikasi.

\section{Implementasi dan Uji Coba}

\subsection{Implementasi Aplikasi}

Implementasi aplikasi yaitu proses dimana rancangan sistem yang telah dibuat diubah menjadi aplikasi. Berikut ini adalah implementasi Aplikasi Customer Relationship Management (CRM) pada Balai Kesehatan Masyarakat Muslimat (BKM) Kepanjen yang dibuat.

\section{a. Halaman Utama Pengunjung}

Halaman utama pengunjung adalah halaman yang akan ditampilkan pertama kali ketika pengunjung mengakses sistem.

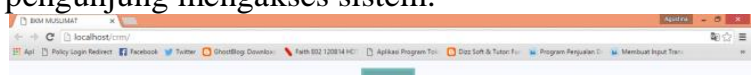

Gambar 5. Halaman Utama Pengunjung

b. Halaman Kuesioner

Halaman kuesioner adalah halaman yang digunakan untuk survey pelanggan atau pasien yang telah berkunjung ke BKM Muslimat.

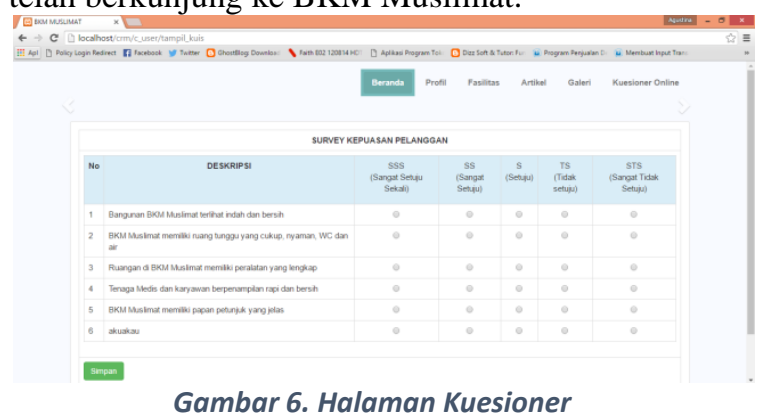

c. Halaman Login

Halaman login adalah halaman untuk memasuki halaman yang diakses oleh user (pengguna) tertentu. User yang melakukan login, yaitu admin, dokter, rekam medis, dan customer service.

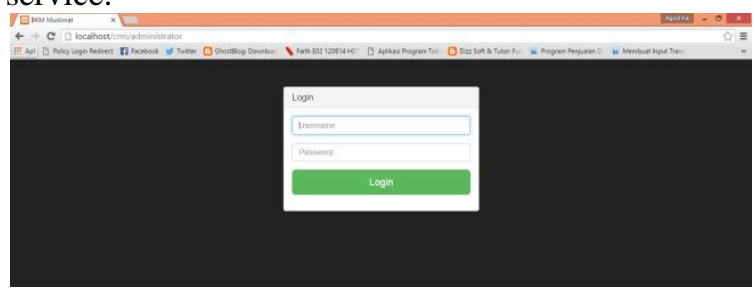

Gambar 7. Halaman Login 


\section{d. Halaman Analisa Data}

Halaman analisa data adalah halaman untuk menampilkan pengolahan data kepuasan pelanggan dari kuesioner yang telah masuk.

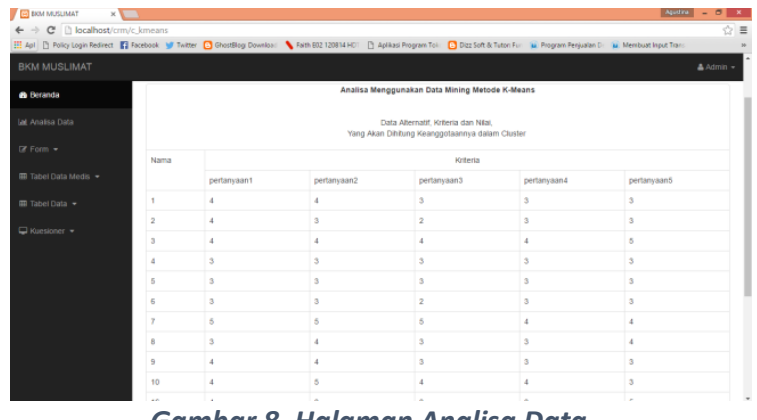

Gambar 8. Halaman Analisa Data

\subsection{Kasus dan Hasil Uji Coba}

Pengujian perangkat lunak ini menggunakan metode pengujian Black Box. Pengujian Black Box berfokus pada persyaratan fungsional perangat lunak yang dibuat.

a. Login

Tabel 1. Login

\begin{tabular}{|c|c|c|}
\hline \multicolumn{3}{|c|}{ Kasus dan Hasil Uji(Data Normal) } \\
\hline $\begin{array}{c}\text { Data } \\
\text { Masukan }\end{array}$ & $\begin{array}{c}\text { Yang } \\
\text { Diharapkan }\end{array}$ & Pengamatan \\
\hline $\begin{array}{l}\text { Data login } \\
\text { Admin } \\
\text { Username : } \\
\text { admin } \\
\text { Password : } \\
\text { admin }\end{array}$ & $\begin{array}{l}\text { Tercantum pada } \\
\text { textbox } \\
\text { username dan } \\
\text { password }\end{array}$ & $\begin{array}{l}\text { Dapat mengisi } \\
\text { textbox } \\
\text { username dan } \\
\text { password } \\
\text { berupa bulat } \\
\text { hitam. }\end{array}$ \\
\hline $\begin{array}{l}\text { Klik } \\
\text { Tombol } \\
\text { Login }\end{array}$ & $\begin{array}{l}\text { Dapat masuk ke } \\
\text { form } \\
\text { selanjutnya }\end{array}$ & $\begin{array}{l}\text { Tombol login } \\
\text { dapat berfungsi } \\
\text { sesuai yang } \\
\text { diharapkan }\end{array}$ \\
\hline \multicolumn{3}{|c|}{ Kasus dan Hasil Uji(Data Salah) } \\
\hline $\begin{array}{c}\text { Data } \\
\text { Masukan }\end{array}$ & $\begin{array}{l}\text { Yang } \\
\text { Diharapkan }\end{array}$ & Pengamatan \\
\hline $\begin{array}{l}\text { Data login } \\
\text { Admin } \\
\text { Username : } \\
\text { admin } \\
\text { Password : } \\
\text { admin }\end{array}$ & \begin{tabular}{l}
\multicolumn{2}{c}{ Tidak } \\
tercantum pada \\
textbox \\
username dan \\
password
\end{tabular} & $\begin{array}{l}\text { Tidak } \\
\text { dapat mengisi } \\
\text { textbox } \\
\text { username dan } \\
\text { password } \\
\text { berupa bulat } \\
\text { hitam. }\end{array}$ \\
\hline $\begin{array}{l}\text { Klik } \\
\text { Tombol } \\
\text { Login }\end{array}$ & $\begin{array}{l}\text { Tidak } \\
\text { dapat Login }\end{array}$ & $\begin{array}{lr} & \text { Tombol } \\
\text { login } & \text { tidak } \\
\text { dapat berfungsi } & \text { sesuai yang } \\
\text { diharapkan }\end{array}$ \\
\hline
\end{tabular}

b. Input Data
Tabel 2. Input Data

\begin{tabular}{|c|c|c|}
\hline \multicolumn{3}{|c|}{ Kasus dan Hasil Uji(Data Normal) } \\
\hline $\begin{array}{l}\text { Data } \\
\text { Masukan }\end{array}$ & $\begin{array}{l}\text { Yang } \\
\text { Diharapkan }\end{array}$ & Pengamatan \\
\hline $\begin{array}{l}\text { Klik Tombol } \\
\text { Simpan }\end{array}$ & $\begin{array}{l}\text { Dapat } \\
\text { menyimpan } \\
\text { record ke dalam } \\
\text { database }\end{array}$ & $\begin{array}{l}\text { Data dapat } \\
\text { disimpan }\end{array}$ \\
\hline $\begin{array}{l}\text { Klik Tombol } \\
\text { Batal }\end{array}$ & $\begin{array}{l}\text { Dapat kembali } \\
\text { ke tampilan } \\
\text { sebelumnya }\end{array}$ & $\begin{array}{ll}\text { Kembali ke } \\
\text { tampilan } \\
\text { sebelumnya } \\
\end{array}$ \\
\hline \multicolumn{3}{|c|}{ Kasus dan Hasil Uji(Data Salah) } \\
\hline $\begin{array}{c}\text { Data } \\
\text { Masukan }\end{array}$ & $\begin{array}{c}\text { Yang } \\
\text { Diharapkan }\end{array}$ & Pengamatan \\
\hline $\begin{array}{l}\text { Klik Tombol } \\
\text { Simpan }\end{array}$ & $\begin{array}{l}\text { Tidak } \\
\text { tercantum pada } \\
\text { textbox } \\
\text { username dan } \\
\text { password }\end{array}$ & $\begin{array}{l}\text { Data tidak } \\
\text { dapat disimpan }\end{array}$ \\
\hline $\begin{array}{l}\text { Klik Tombol } \\
\text { Batal }\end{array}$ & $\begin{array}{l}\text { Tidak dapat } \\
\text { Login }\end{array}$ & $\begin{array}{l}\text { Tidak kembali } \\
\text { ke tampilan } \\
\text { sebelumnya }\end{array}$ \\
\hline
\end{tabular}

c. Info Data

Tabel 3. Info Data

\begin{tabular}{|c|c|c|}
\hline \multicolumn{3}{|c|}{ Kasus dan Hasil Uji(Data Normal) } \\
\hline $\begin{array}{c}\text { Data } \\
\text { Masukan }\end{array}$ & $\begin{array}{c}\text { Yang } \\
\text { Diharapkan }\end{array}$ & Pengamatan \\
\hline $\begin{array}{l}\text { Klik fitur } \\
\text { yang } \\
\text { diinginkan }\end{array}$ & $\begin{array}{l}\text { Menampilkan } \\
\text { data yang } \\
\text { dinginkan }\end{array}$ & $\begin{array}{l}\text { Menampilkan } \\
\text { data sesuai } \\
\text { yang } \\
\text { diharapkan } \\
\end{array}$ \\
\hline \multicolumn{3}{|c|}{ Kasus dan Hasil Uji(Data Salah) } \\
\hline $\begin{array}{l}\text { Data } \\
\text { Masukan }\end{array}$ & $\begin{array}{c}\text { Yang } \\
\text { Diharapkan } \\
\end{array}$ & Pengamatan \\
\hline $\begin{array}{l}\text { Klik fitur } \\
\text { yang } \\
\text { diinginkan }\end{array}$ & $\begin{array}{l}\text { Tidak dapat } \\
\text { menampilkan } \\
\text { data yang } \\
\text { dinginkan }\end{array}$ & $\begin{array}{l}\text { Tidak } \\
\text { menampilkan } \\
\text { data sesuai } \\
\text { yang } \\
\text { diharapkan }\end{array}$ \\
\hline
\end{tabular}

\section{Kesimpulan dan Saran}

Dari hasil analisis dan perancangan telah berhasil dibuat suatu aplikasi Customer Relationship Management (CRM). Dan secara fungsional aplikasi dapat mengeluarkan hasil sesuai yang diharapkan. Aplikasi ini mampu dipakai untuk menganalisa data kepuasan pelanggan untuk peningkatan mutu pelayanan terhadap pasien di BKM Muslimat menggunakan Algoritme K-means Clustering. Pada akhirnya sasaran akhir dari CRM untuk memberikan layanan terbaik kepada pasien dapat terpenuhi. Sehingga terciptanya loyalitas yang tinggi dari para pelanggan.

Daftar Pustaka: 
Adelia, dkk, (2011): Implementasi Customer Relationship Management (CRM) pada Sistem Reservasi Hotel berbasis Website dan Dekstop, Jurnal Sistem Informasi, Vol. 6, pp. 113-126.

Afrina, M., (2013): Rancang Bangun Electronic Relationship Management (E-CRM) sebagai Sistem Informasi Dalam Peningkatan Layanan Perpustakaan Digital Fakultas Ilmu Komputer Unsri, Jurnal Sistem Informasi (JSI), Vol. 5, pp. 629-644.

Budiaji, W., (2013): Skala Pengukuran dan Jumlah Respon Skala Likert, Jurnal Ilmu Pertanian dan Perikanan 2, pp. 2.

Dyantina, O., (2012): Penerapan Customer Relationship Management (CRM) Berbasis Web (Studi Kasus Pada Sistem Informasi Pemasaran di Toko YEN-YEN), Jurnal Sistem Informasi (JSI) 4, pp. 516-529.

Kaswidjanti, W., (2011): Aplikasi e-CRM Berbasis Web pada Rumah Sakit, Telematika 8, pp. 17-24.

Laudon, K. C., (2008): Sistem Informasi Manajemen, Jakarta, Salemba Empat.

Prasetyo, E., (2012): Data Mining: Konsep dan Aplikasi Menggunakan MATLAB, Yogyakarta, Andi.

Sidik, B., (2012): Framework Codeigniter. Cetakan: I, Bandung, Informatika.

Susanto, S., (2010), Pengantar Data Mining Menggali Pengetahuan dari Bongkahan Data, Yogyakarta, Andi.rd ed., New York, 